\title{
International Journal of Advanced Multidisciplinary Research
}

ISSN: 2393-8870

www.ijarm.com

DOI: 10.22192/ijamr

Volume 4, Issue 6 -2017

Research Article

DOI: http://dx.doi.org/10.22192/ijamr.2017.04.06.009

\section{Bibliometric analysis of Research Productivity of Top Ten Universities of Odisha in Indian Journals}

\author{
Mr. Karan Singh \\ $\mathrm{Ph}$. D Scholar, Sambalpur University, Odisha \\ Corresponding Author: Karan4u358@gmail.com
}

Keywords

Authorship Patterns, Bibliometric analysis, Universities of Odisha, Indian journals, LIS Research

\section{Abstract}

The paper examines various pattern of the articles published in the Indian journals of top ten Universities of Odisha for the period of 2004 to 2016 and expose the results for the publications through bibliometric analysis. The paper represents the bibliometric analysis of the journal in order to evaluate the growth pattern of research productivity published in Indian journals. It explains and presents an analysis of 1858 research papers published in the Top ten universities of Odisha downloaded from Scopus online database. The study aims to analyzing research output cover mainly the number of articles, authorship pattern, subject wise distribution of articles, average number of references per articles, forms of documents cited, year wise distribution of cited journals etc. All the studies point towards the merits and weakness of the journal which will be helpful for its further development of Indian journals research output. The prediction of the authors gives a contribution to the area of LIS research by assisting the researchers, librarians and professionals as a whole.

\section{Introduction}

Bibliometric is a technique or a tool of information manager, which called Quantitative Science. Bibliometrics is a type of research method used in Library and Information science and an emerging area of research in this field. Bibliometric has practical applications in the evaluation library operations and surveys through statistical technique to make a quantitative analysis possible it is also useful in the study and measurement of publication patterns forms of literature on one subject or the other. Bibliometrics is the latest technique, used to understand utilization of published / unpublished resource of information. The main source of published source of information is The Primary sources, Secondary sources and tertiary sources main sources of published sources of information. A bibliometric analysis of the articles published in journals demonstrates the growth and pattern in a subject area.
Bibliometrics involves the analysis of a set a publication characterized by bibliographical derivatives such as Authors, place of publication, citation ,co-citation analysis etc. another major area of bibliometrics research is the citation analysis.

Universities are centres of higher education emphasising research and development. Many universities in India have been identified as centres of excellence in order to carry out high quality research in different subjects. There is a huge research funding to the universities from many organizations such as UGC, NAAC, HRD, Higher Education Department, Indian National Science Academy and many more. These research appraisals have been carried out by undertaking bibliometric analysis of publications in different citation databases 
such as Scopus, World of Science, and Google Scholar etc. As a result majority of journals published in our country are debarred from the ambit of such databases .As only a little portion of research from Indian universities is published in journals which are available and could be used as tool for appraisal of Indian research.

\section{Research Objectives}

The present study attempts to provide a more detail account of the research productivity and bibliometric dimensions of research publications of Top Ten Universities of Orissa. The objectives of the study are to understand and to find the bibliometric distinctiveness of the Indian Journal published in universities of Odisha. The objectives are listed as follows:

- To study the quantum of Indian research papers from the universities in Odisha published in Indian journals

- To study the year wise distribution of research in the universities in Odisha

- To study the authorship pattern

- To identify the length of Indian journal.

- T know the subject categories

- To make a comparison of research from different universities in Odisha

- To find out the strength and weakness of research in different disciplines

\section{Research Methodology and Scope}

The present study is based on bibliometric analysis; in this research the keyword "Productivity of Ten Universities of Odisha in Indian Journals" has been taken as search term to search the Scopus online database. Search approach is limited to the appearance of the keyword in the title of the publication and the time range of published literature is 2004 to 2016. All the bibliographic details were noted and a computerized database is then created for in depth analysis. A total of 1858 citation was retrieved having keyword "Productivity of Ten Universities of Odisha in Indian Journals" in the title of the document. All citations are then exported to MS-Excel sheet for analysis. The present study is also based on the quantitative measures rather than the quality of the content of documents.

The present study has been proposed to undertake a bibliometric analysis of research in the universities in
Odisha with specific reference to Indian journals which are search the Scopus online database .The scope of the study will only cover the following Top 10 universities in Odisha:

- Utkal University, Bhubaneswar

- Berhampur University, Berhampur

- Revenshaw University, Cuttack

- Sambalpur University, Sambalpur

- Veer Surendra Sai Technical University, Burla, Sambalpur

- Sikhya O Anusandhan (SOA) University, Bhubaneswar

- North Orissa University, Baripada

- Fakir Mohan University, Balasore

- $\quad$ KIIT University, Bhubaneswar

- Orissa University of Agriculture and Technology (OUAT), Bhubaneswar

\section{Review of Literature}

A literature review is an evaluative report of the studies found in the literature related to your selected area. The review should describe, summarize, evaluate and clarify this literature. Several bibliometric studies have been under taken by various researchers across the globe to understand the publication distribution pattern of a particular journal related to different subject fields including LIS. It also identifies the gap in the literature and side by side directs the way in filling such gaps with the new knowledge.

* MKG Rajev and Saju Joseph (2016) in their stud "A Bibliometric Analysis on Malaysian Journal of Library and Information Science", the study has been carried out with the comparison of the previous studies done by other authors. The study reveals that 142 articles published in the journal for the period from 2007 to 2013. The year 2011 is the most productive year with 21 articles during the study period. The study reveals that the highest number of articles are published in the second category which is the domain of 'Information seeking behaviour of the user' It is also found that 56 articles that is the maximum number of articles (56 articles) were authored and coauthored by Malaysian authors and maximum of 184 citations were received for the published articles for the study period.

* A study conducted by Maharana et. al (2006), on "Scholarly use of web resources in LIS research: a citation analysis. In India the essential purpose of this paper is to measure the amount of web resources used for scholarly contributions in the area of library and 
Int. J. Adv. Multidiscip. Res. (2017). 4(6): 80-89

information science (LIS). The study revealed that 292 (34.88 per cent) out of 837 were web citations, proving a significant correlation between the use of Internet resources and research productivity of LIS professionals in India.

* Manthiramoorthi M. and Thamaraiselvi M. (2016) "Bibliometric Analysis of National Conference Proceedings- A Study", in his paper deals with the Bibliometric analysis of 13th UGC Sponsored national conference proceedings organized by $\mathrm{PG}$ and Research DLIS Bishop Heber College, Tirchy. The paper analyzes a Bibliometric study of 53 articles was published in the national conference proceedings. The study aims to analyzes the topic-wise distribution of articles, category-wise distribution of contributions, authorship patterns, and institutions-wise distribution of contributions.

* Björk B C \& Hedlund T (2004) in their study "A formalised model of the scientific publication process", the common dominators will be to study costs per publications following through the systems. In addition to cost modeling the model could also prove useful in providing a road map pointing out the position of a number of different initiatives for increasing access to scientific publications, with in the all overall system of scholarly communication

* Giri R \& Das A K (2011) in their study "Indian Citation Index: a new web platform for measuring performance of Indian research periodicals" ICI is an important and bold step in the world of Indian research and development. It will greatly enhance the visibility of Indian R\&D literature and knowledge products to global research communities and collaborative networks which may automatically attract more citations, more prestige to Indian research outputs and more global research collaborations. So far, ICI is a very user friendly database with a reasonable response time. But as of this date, it covers only a small fraction of identified sources.

\section{Limitations of the Study}

The present study has been characterized with the following limitations:

- It includes literature growth study of Universities of Odisha publication in Indian journals, indexed only in the Scopus database from 2004 to 2016. (Limitation by source database)
- It includes only Top Ten Universities Odisha Indians journals publications document. (Limitations by title of publications)

\section{Data Analysis and Discussion}

In the Present study the data are collected from the Scopus Online database from the time period 20042016, Filter the only 1858 numbers of research publications in Universities of Odisha, which has been published in last 12 years, but the chronological Classification of papers as made their actual year of the publications in the concerned journals. Indicated in different tables of this paper varies from it because, the papers have been gathered for this study are indexed under the database from 2004-2016 important papers which were published in Indian Journals productivity on ten universities of Odisha.

\subsection{Authorship pattern comparison}

Authorship pattern discloses how the papers are distributed among the author; level of author collaboration etc. authorship pattern is one of the very important bibliometric indicators in order to access the degree of collaboration of authors.

Therefore, the Degree of Collaboration of research at $\mathrm{C}=\mathrm{Nm} / \mathrm{Nm}+\mathrm{Ns}=0.92$

Where, $\mathrm{C}=$ Degree of collaboration in a discipline $\mathrm{Nm}=$ number of multi-authored papers in the discipline

Ns = number of single-authored papers in the discipline

Authorship pattern is one of the most significant Bibliometric indicators in order to assess the degree of collaboration of the authors in a particular discipline or in institution and Year wise Authorship Pattern are indicate the table. 
Int. J. Adv. Multidiscip. Res. (2017). 4(6): 80-89

Table 1-Authorship pattern comparison of 10 universities of Odisha

\begin{tabular}{|c|c|c|c|c|c|c|c|}
\hline $\begin{array}{l}\text { Name of the } \\
\text { universities }\end{array}$ & $\begin{array}{l}\text { Single } \\
\text { Author }\end{array}$ & $\begin{array}{l}2 \\
\text { Authors }\end{array}$ & $\begin{array}{l}3 \\
\text { Authors }\end{array}$ & $\begin{array}{l}4 \\
\text { Author: }\end{array}$ & $\begin{array}{l}5 \\
\text { Authors }\end{array}$ & $\begin{array}{l}\text { More } \\
\text { than } 5 \\
\text { authors }\end{array}$ & $\begin{array}{l}\text { Degree of } \\
\text { Collaboratio } \\
\text { n }\end{array}$ \\
\hline Utkal University & 36 & 120 & 152 & 81 & 35 & 33 & 0.921225 \\
\hline $\begin{array}{l}\text { Berhampur } \\
\text { University }\end{array}$ & 21 & 72 & 83 & 26 & 15 & 15 & 0.909483 \\
\hline $\begin{array}{l}\text { Ravenshaw } \\
\text { University (RU) }\end{array}$ & 18 & 55 & 56 & 21 & 5 & 9 & 0.890244 \\
\hline $\begin{array}{l}\text { Sambalpur Universit } \\
\text { y (SU) }\end{array}$ & 19 & 60 & 40 & 16 & 12 & 8 & 0.877419 \\
\hline $\begin{array}{l}\text { North } \quad \text { Orissa } \\
\text { University (NOU) }\end{array}$ & 14 & 35 & 58 & 30 & 12 & 15 & 0.914634 \\
\hline $\begin{array}{l}\text { Fakir } \quad \text { Mohan } \\
\text { University (FMU) }\end{array}$ & 12 & 18 & 35 & 9 & 4 & 2 & 0.85 \\
\hline $\begin{array}{lr}\text { Veer Surendra Sai } \\
\text { University } & \text { of } \\
\text { Technology } & \\
\text { (VSSUT) } & \end{array}$ & 5 & 15 & 28 & 3 & 3 & 3 & 0.912281 \\
\hline $\begin{array}{l}\text { Siksha 'O' } \\
\text { Anusandhan } \\
\text { University (SOAU) }\end{array}$ & 5 & 14 & 17 & 9 & 2 & 7 & 0.907407 \\
\hline $\begin{array}{l}\text { K I I T University } \\
\text { (KIITU) }\end{array}$ & 9 & 23 & 10 & 3 & 1 & 4 & 0.82 \\
\hline $\begin{array}{l}\text { Orissa University of } \\
\text { Agriculture and } \\
\text { Technology } \\
\text { (OUAT) }\end{array}$ & 40 & 120 & 135 & 78 & 37 & 35 & 0.910112 \\
\hline
\end{tabular}

Graph-1.-Authorship Pattern Comparison of 10 university of Odisha

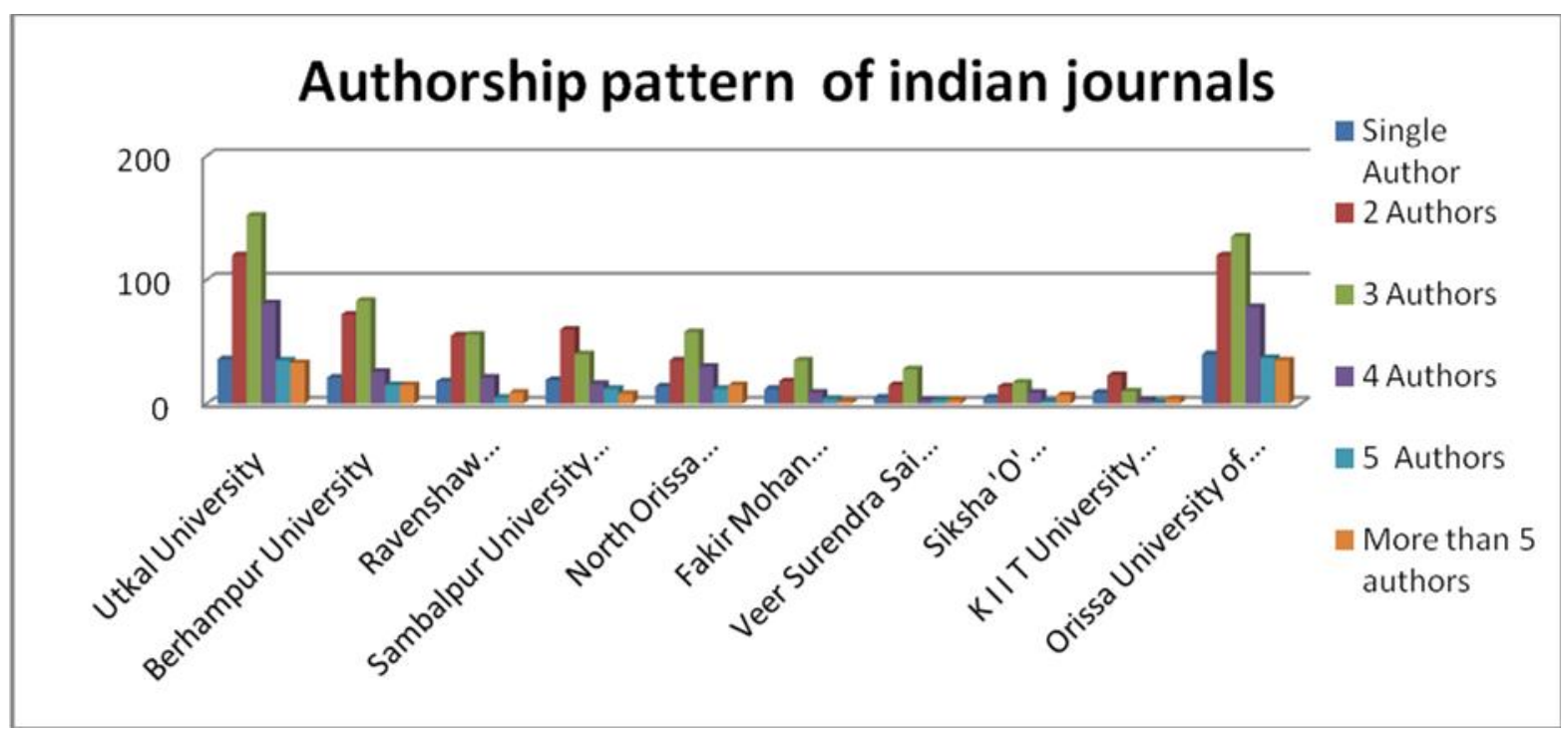


Int. J. Adv. Multidiscip. Res. (2017). 4(6): 80-89

Above Table-1.2 and Graph-1.2 embodies a comparison of authorship patters in the research publications from the 10 Universities of Odisha. It can be seen from the, above table that similar trend as regards to the authorship pattern prevails in almost all the universities of Odisha. Majority of publications from each of these universities are collaboratively authored by two, three and four authors.

\section{2. Year wise growth contribution of Indian journals}

Year-wise Growth of publication is one of the very important Bibliometric indicators in order to assess the year wise degree of growth of publication and to find out the most productive year of publication

Table: 2

\begin{tabular}{|c|c|c|c|c|c|c|c|c|c|c|c|c|c|}
\hline Name of the universities & $\begin{array}{l}201 \\
6\end{array}$ & $\begin{array}{l}201 \\
5\end{array}$ & $\begin{array}{l}201 \\
4\end{array}$ & $\begin{array}{l}201 \\
3\end{array}$ & $\begin{array}{l}201 \\
2\end{array}$ & $\begin{array}{l}201 \\
1\end{array}$ & $\begin{array}{l}201 \\
0\end{array}$ & $\begin{array}{l}200 \\
9\end{array}$ & $\begin{array}{l}200 \\
8\end{array}$ & $\begin{array}{l}200 \\
7\end{array}$ & $\begin{array}{l}200 \\
6\end{array}$ & $\begin{array}{l}200 \\
5\end{array}$ & 2004 \\
\hline Utkal University & 8 & 10 & 10 & 40 & 45 & 35 & 50 & 34 & 37 & 37 & 31 & 40 & 34 \\
\hline Berhampur University & 10 & 15 & 8 & 14 & 19 & 26 & 16 & 25 & 18 & 16 & 24 & 22 & 23 \\
\hline $\begin{array}{l}\text { Ravenshaw University } \\
\text { (RU) }\end{array}$ & 4 & 9 & 4 & 20 & 21 & 21 & 18 & 22 & 10 & 8 & 3 & 7 & 10 \\
\hline $\begin{array}{l}\text { Sambalpur } \\
\text { University (SU) }\end{array}$ & 15 & 25 & 15 & 25 & 30 & 18 & 15 & 13 & 11 & 15 & 26 & 14 & 21 \\
\hline $\begin{array}{l}\text { North Orissa University } \\
\text { (NOU) }\end{array}$ & 8 & 6 & 7 & 13 & 13 & 21 & 21 & 13 & 16 & 12 & 14 & 6 & 0 \\
\hline $\begin{array}{l}\text { Fakir } \text { Mohan } \\
\text { University (FMU) }\end{array}$ & 7 & 10 & 6 & 8 & 11 & 10 & 8 & 8 & 11 & 3 & 8 & 2 & 2 \\
\hline $\begin{array}{lr}\text { Veer Surendra Sai } \\
\text { University } \\
\text { Technology (VSSUT) }\end{array}$ & 5 & 10 & 3 & 2 & 11 & 4 & 2 & 3 & 6 & 4 & 2 & 3 & 2 \\
\hline $\begin{array}{l}\text { Siksha 'O' Anusandhan } \\
\text { University (SOAU) }\end{array}$ & 6 & 9 & 3 & 7 & 6 & 9 & 12 & 3 & 0 & 0 & 0 & 0 & 0 \\
\hline $\begin{array}{lllll}\begin{array}{l}\text { K } \\
\text { (KIITU) }\end{array} & \text { I } & \text { I } & \text { University } \\
\end{array}$ & 12 & 13 & 3 & 15 & 5 & 5 & 5 & 5 & 6 & 3 & 1 & 0 & 1 \\
\hline (OUAT) & 7 & 5 & 9 & 39 & 40 & 38 & 36 & 40 & 40 & 30 & 28 & 30 & 39 \\
\hline
\end{tabular}

Table: 2 above present the data relating to growth of publication of Indian Journals universities of Odisha Research Productivity on 12 years i.e. during 20042016. The Year 2012 is the highest productive year in which 201research papers were published. 2011 is second Highest productive year 187 papers Published. And lowest productive year is 2014 only 68 papers reflected in Scopus database.

\subsection{Citation count of Research Papers}

Citation count of research papers provides an indication of usage of published literature and helps to rank the literature sources. It also indicates the quantum of research on a specific subject. The more research, the more will be the usage of published literature and more citations. The following table: 3 demonstrate the citation pattern of papers on Indian Journals publication in universities of Odisha. As data promulgates that, citation pattern of the articles are unlikely scattered. 
Int. J. Adv. Multidiscip. Res. (2017). 4(6): 80-89

Table: 3

\begin{tabular}{|c|c|c|c|c|c|c|c|c|c|c|}
\hline \multirow{2}{*}{$\begin{array}{l}\text { Time } \\
\text { cited }\end{array}$} & \multicolumn{10}{|c|}{ Nos. of papers } \\
\hline & $\mathbf{U U}$ & BU & RU & SU & NOU & FMU & VSSUT & SOAU & KIITU & OUAT \\
\hline 0 & 380 & 200 & 116 & 112 & 112 & 50 & 30 & 34 & 35 & 335 \\
\hline 1 & 40 & 25 & 18 & 35 & 17 & 15 & 4 & 8 & 5 & 30 \\
\hline 2 & 20 & 15 & 8 & 28 & 8 & 5 & 1 & 1 & 4 & 23 \\
\hline 3 & 6 & 2 & 2 & 6 & 3 & 2 & 0 & 1 & 4 & 8 \\
\hline 4 & 5 & 0 & 1 & 6 & 1 & 0 & 0 & 1 & 0 & 4 \\
\hline 5 & 4 & 1 & 4 & 5 & 1 & 1 & 0 & 0 & 0 & 4 \\
\hline 6 & 2 & 1 & 0 & 0 & 0 & 1 & 0 & 0 & 0 & 3 \\
\hline 7 & 1 & 1 & 4 & 0 & 2 & 1 & 0 & 0 & 0 & 0 \\
\hline 8 & 0 & 1 & 0 & 20 & 0 & 0 & 0 & 1 & 0 & 2 \\
\hline 9 & 2 & 0 & 5 & 0 & 0 & 0 & 0 & 0 & 0 & 0 \\
\hline 10 & 0 & 0 & 0 & 0 & 0 & 0 & 0 & 0 & 0 & 1 \\
\hline 11 & 0 & 1 & 0 & 0 & 0 & 0 & 0 & 0 & 0 & 1 \\
\hline 12 & 0 & 0 & 0 & 0 & 1 & 0 & 0 & 0 & 0 & 1 \\
\hline 21 & 0 & 0 & 0 & 20 & 0 & 0 & 0 & 0 & 0 & 0 \\
\hline
\end{tabular}

Graph: 2

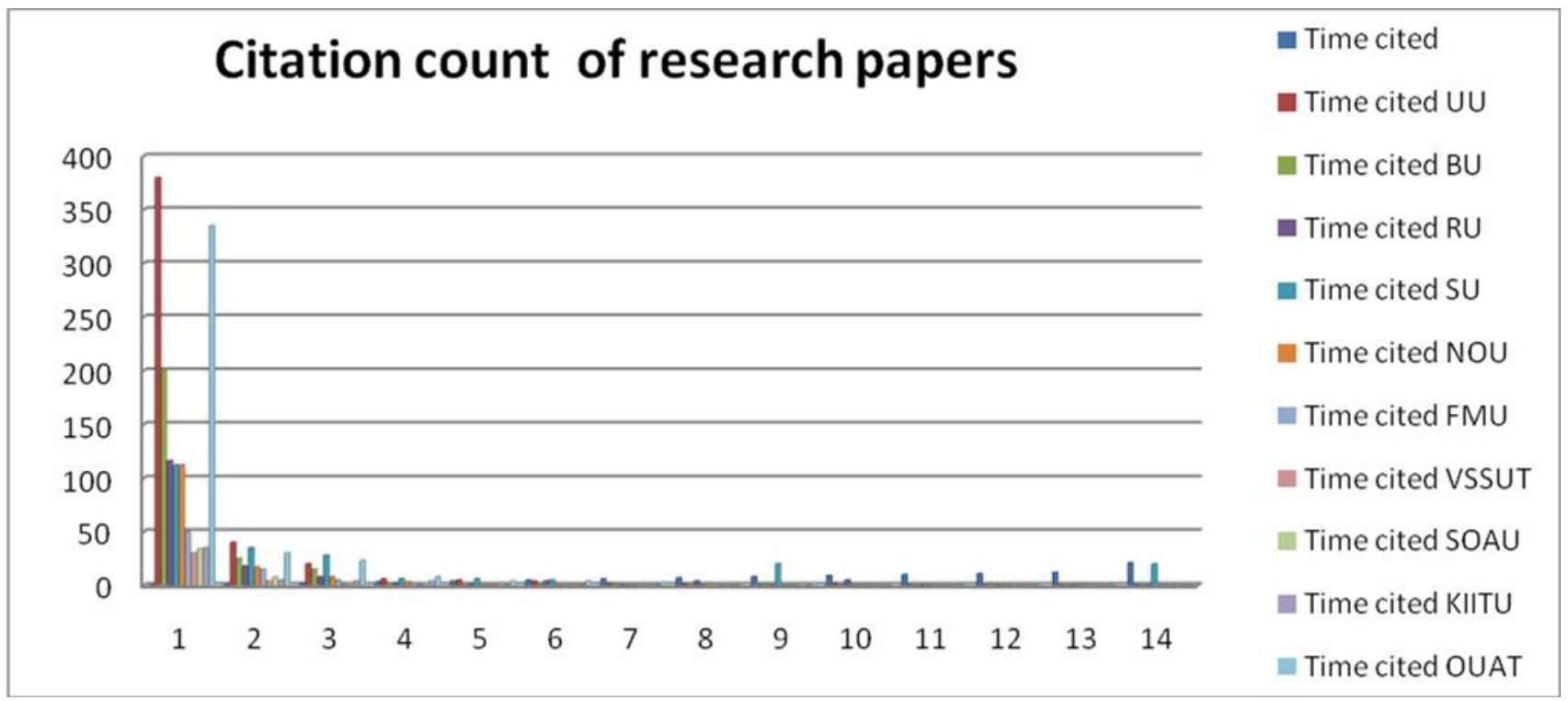

Above Table-1.3 and Graph-1.2 embodies a Citation wise comparison in the research publications from the 10 Universities of Odisha. It can be seen from the, above table that similar trend as regards to the Citation wise comparison prevails in almost all the universities of Odisha. Majority of publications from each of these universities are collaboratively cited 0 times.

\section{4. Types of Documents publication in Indian Journals}

In the field of indian journals odisha of universities research papers published in various document types of publication in world. The major document types of research publications on Agriculture include journal articles, conference paper, working papers, book chapters, etc. In order to find out the major document types of Indian Journals publication, the following data have been collected. 
Int. J. Adv. Multidiscip. Res. (2017). 4(6): 80-89

Table: 4

\begin{tabular}{|l|l|l|l|l|l|l|l|l|l|l|}
\hline $\begin{array}{l}\text { Type of } \\
\text { document }\end{array}$ & UU & BU & RU & SU & NOU & FMU & VSSUT & SOAU & KIITU & OUAT \\
\hline $\begin{array}{l}\text { RESEARCH } \\
\text { ARTICLE }\end{array}$ & 400 & 204 & 150 & 210 & 130 & 80 & 51 & 39 & 45 & 352 \\
\hline $\begin{array}{l}\text { CONFORENCE } \\
\text { PAPERS }\end{array}$ & 14 & 10 & 10 & 18 & 8 & 8 & 4 & 3 & 2 & 51 \\
\hline Books Chapter & 8 & 0 & 2 & 12 & 3 & 3 & 4 & 1 & 2 & 1 \\
\hline $\begin{array}{l}\text { Review } \\
\text { ARTICLE }\end{array}$ & 0 & 6 & 1 & 0 & 2 & 1 & 0 & 1 & 0 & 2 \\
\hline Short Survey & 0 & 3 & 5 & 1 & 1 & 0 & 0 & 0 & 1 & 1 \\
\hline Note & 0 & 0 & 0 & 0 & 1 & 0 & 0 & 0 & 0 & 1 \\
\hline Erratum & 0 & 0 & 0 & 5 & 0 & 0 & 1 & 0 & 0 & 0 \\
\hline
\end{tabular}

Table-4 and Graph-3 displays the mapping of research papers published in various document types of publication. The above table indicates that maximum number documents belong to 'articles' constituting 1661 research papers followed by Conference papers 128.

\subsection{Subject Wise distribution of Indian publications}

\begin{tabular}{|c|c|c|c|}
\hline Social science & Pure science & $\begin{array}{ll}\text { Arts } & \text { and } \\
\text { humanities }\end{array}$ & Applied science \& technology \\
\hline Anthropology(32) & environmental science(54) & $\begin{array}{c}\text { Arts } \\
\text { Humanities(8) }\end{array}$ & Agriculture(203) \\
\hline $\begin{array}{l}\text { Library and information } \\
\text { science }(75)\end{array}$ & Environment and ecology (3) & & Business and marketing(8) \\
\hline Social science $(83)$ & Botany (80) & & Health science(103) \\
\hline Rural development(8) & $\begin{array}{l}\text { Astronomy, astrophysics, space } \\
\text { and geodesy }(5)\end{array}$ & & Management(36) \\
\hline Economics(28) & Biological science(260) & & Textile(3) \\
\hline Education(25) & Chemistry(183) & & $\begin{array}{rrr}\begin{array}{c}\text { Computer } \\
\text { technology }(32)\end{array} & & \text { science } \\
\end{array}$ \\
\hline $\operatorname{Law}(5)$ & Earth and geological scienc(33) & & $\begin{array}{c}\text { Engineering science and } \\
\text { technology }(76)\end{array}$ \\
\hline Psychology(4) & Material science $(8)$ & & $\begin{array}{rrr}\begin{array}{c}\text { General } \\
\text { technology }(54)\end{array} & \text { science } & \& \\
\end{array}$ \\
\hline $\begin{array}{cccc}\begin{array}{c}\text { Studies } \\
\text { tribals(3) }\end{array} & \text { of tribes and } \\
\end{array}$ & Mathematics(48) & & $\begin{array}{ll}\begin{array}{l}\text { Nanoscience } \\
\text { nanotechnology (2) }\end{array} & \text { and } \\
\end{array}$ \\
\hline & $\begin{array}{c}\text { Pharmacology } \\
\text { pharmaceutical science }(84)\end{array}$ & & Forestry(34) \\
\hline & Physics(111) & & Remote sensing(1) \\
\hline & Veterinary science(41) & & \\
\hline & Zoology(46) & & \\
\hline & Food and beverage science(3) & & \\
\hline & Biotechnology(15) & & \\
\hline & Fishery(25) & & \\
\hline & $\begin{array}{l}\text { History and philosophy of } \\
\text { science and knowledge(14) }\end{array}$ & & \\
\hline & $\begin{array}{l}\text { Oceanography and marine } \\
\text { science(22) }\end{array}$ & & \\
\hline Total no of article $=263$ & Total no of article $=1035$ & $\begin{array}{l}\text { Total no of } \\
\text { article=8 }\end{array}$ & Total no of article $=552$ \\
\hline
\end{tabular}




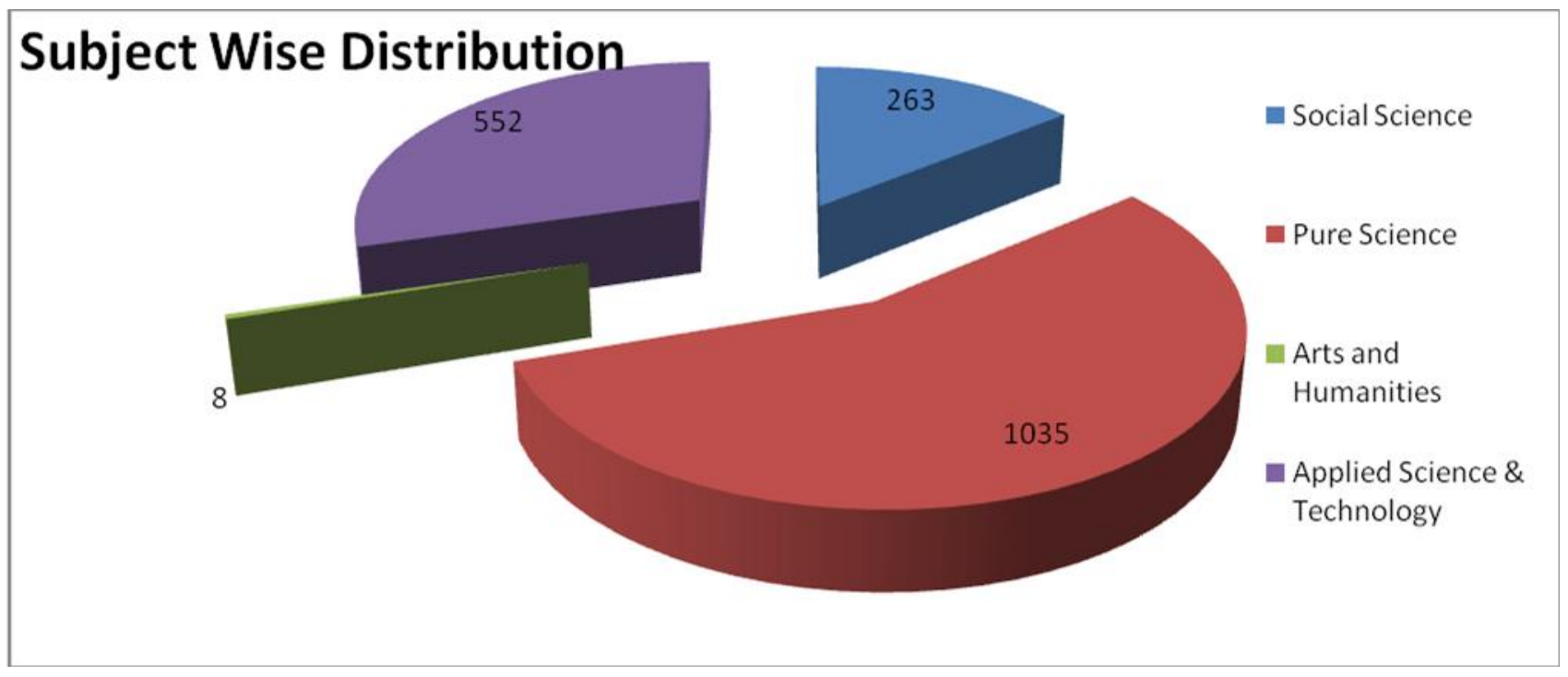

Table: 5 and Graph: 3 - shows that the subject divides in to 4 categories, those are Social Science, pure science arts and humanities and applied science and technology. Among of them in the field of pure science highest 1035 paper published greatest interest of research among the researchers of Odisha is in the area of Biological science out of 260.

\section{Findings}

As a result of systematic analysis of data obtained from the present study, in the previous chapters, the investigator observes the following facts about the research in mapping of research publication in ten Universities of Odisha. The following major findings are as follows:

Out of 1858 numbers of publications only 179 are single authored and rest 1679 numbers are coauthored. So it is evident that authors of top ten Universities in odisha have a tendency to work in collaboration researchers.

Research publications of Indian journals productive in Odisha; during 2004 to 2016 have published 1858of articles and the year 2012 is found to be most productive year having highest number of publications i.e. 201 number of research papers.

335 is highest citation in this data and Out of 1835 numbers of Publication 1424 Research papers is
Zero time of Citation and Sambalpur University is published research papers total 332 time cited.

$>\quad$ Maximum 1661 numbers of publications on 10 universities of Odisha Research papers are "Journal articles". Hence "journal articles" are primary medium of communication among the researchers in the field of Universities research publication.

Highest number of publication in Biological science (260) under Pure Science 1035 subject.

\section{Comparison of $\mathbf{1 0}$ universities of Odisha}

- Similar trend as regards to the authorship pattern prevails in almost all the universities of Odisha. Majority of publications from each of these universities are collaboratively authored by two, three and four authors with the Degree collaboration more than 0.90 .

- Similar trend as regards to the Citation wise comparison prevails in almost all the universities of Odisha. Majority of publications suffer from no citation or low citation.

- Similar trend as regards to the document type wise comparison prevails in almost all the universities of Odisha. Majority of publications from each of these universities are Research Articles.

- Highest no. of papers published in the field of pure science (1035) out of 1858 papers of ten universities of Odisha. 


\section{Suggestions}

The last part of any research is not only to find out problems but also to provide some suggestions to irradiate the problem or minimize them to the extent possible. From the Experience of the present investigations, the investigators have put the following suggestions.

1. Emphasis should also be laid on more volume of publications by universities of Odisha in future times to come.

2. Improvement of the quality of content, peer review system and quality in production is required for upgrading the standards of the Indian journals.

3. The authors from international journals should be invited to publish their papers in Indian Journals.

4. More and more journals of Indian origin needed to be included in international databases.

5. Universities which have been identified as the Centre of Excellence may start their journal publications showcasing their research.

\section{Conclusion}

In the present study may useful for understanding the research and development activities, measuring the relative growth, scattering of journal and core journals. It helps in the making research and development policies for improving the productivity of authors of the universities of Odisha in various fields. University play vital role for develop their quality Research skills in the field of higher education. Improve qualities of research papers required for upgrading the standards of the Indian journals. The Bibliometric study to analyze Indian Journals contribution to Top Ten Universities of Odisha based on Scopus Online database revealed that Indian journals has published 1858 papers in various fields of from 2004 to 2016. The maximum numbers of contributions are three authors with 614. Maximum 1661 numbers of publications on 10 universities of Odisha Research papers are "Journal articles". Hence "journal articles" are primary medium of communication among the researchers in the field of Universities research publication. Bibliometric method has been applied to study the growth of literature in various fields in quantitative terms. Thus, the present study also employs bibliometric techniques to make an assessment of various dimensions of Indian journals productivity in universities of Odisha based.

\section{References}

1. Majhi,S. and Maharana, B. (2012). Research productivity of physical science disciplines in Sambalpur University: A scientometric study. Research world- journal of arts, science commerce, III (4.I). [Online] http://www.academia.edu/3470903/

2. Maharana, R.K. \& Das, P. (2013). Research publication trend of Utkal University's researchers indexed in Scopus during 2008 to 2012: a bibliometric analysis. Library Philosophy and Practice. [Online] http://www.digitalcommons.unl.edu/cgi/viewc ontent.cgi?article $=2411 \&$ context...

3. MKG Rajev and Saju Joseph (2016) A Bibliometric Analysis on Malaysian Journal of Library and Information Science, International Research: Journal of Library \& Information Science | Vol.6 No.1, March, pp-159-174

4. 2. Manthiramoorthi M. and Thamaraiselvi M.(2016) Bibliometric Analysis of National Conference Proceedings- A Study ,International Research: Journal of Library \& Information Science | Vol.6 No.1, March, pp104-111

5. 3. K. T. Naheem (2016) Library Progress (International): A bibliomterc study, Library Progress (International), Vol. 36 issue-1, pp.43-53

6. Björk, B. C. \& Hedlund, T. (2004). A formalised model of the scientific publication process. Online Information Review, 28(1). [Online]

http://www.emeraldinsight.com/doi/pdfplus/1 $0.1108 / 00012531211263102$

7. Giri, R. \& Das, A .K. (2011). Indian Citation Index: a new web platform for measuring performance of Indian research periodicals. Library Hi Tech News, 28(3). [Online] http://www.emeraldinsight.com/doi/pdfplus/1 $0.1108 / 07419051111145154$

8. Yadav, B \&\& Yadav, M. (2014). Resources, facilities and services of the Indian citation index (ICI). Library Hi Tech News, 31(4). [Online] http://www.emeraldinsight.com/doi/pdfplus/1 0.1108/LHTN-02-2014-0008 


\section{Webliographical references}

1. utkaluniversity.ac.in/

2. bamu.nic.in/

3. https://plus.google.com/116089023051701939

217/about?gl=in\&hl=en

4. www.suniv.ac.in/

5. www.nou.nic.in/

6. www.fmuniversity.nic.in/

7. www.vssut.ac.in/

8. www.soauniversity.ac.in/

9. www.kiit.ac.in/

10. www.ouat.ac.in/

\begin{tabular}{|c|c|}
\hline \multicolumn{2}{|c|}{ Access this Article in Online } \\
\hline \multirow{2}{*}{ 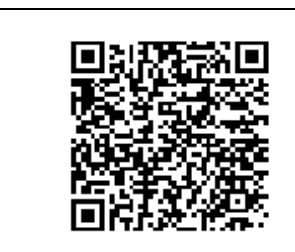 } & $\begin{array}{l}\text { Website: } \\
\text { www.ijarm.com }\end{array}$ \\
\hline & \multirow[t]{2}{*}{$\begin{array}{l}\text { Subject: } \\
\text { Library Science }\end{array}$} \\
\hline $\begin{array}{l}\text { Quick Response } \\
\text { Code }\end{array}$ & \\
\hline $\mathrm{I}: 10.22192$ & 7.04 .06 .0 \\
\hline
\end{tabular}

How to cite this article:

Karan Singh. (2017). Bibliometric analysis of Research Productivity of Top Ten Universities of Odisha in Indian Journals. Int. J. Adv. Multidiscip. Res. 4(6): 80-89.

DOI: http://dx.doi.org/10.22192/ijamr.2017.04.06.009 